\title{
JUBILATA ŻYCIORYS ONOMASTYCZNY
}

\author{
Władysław Makarski \\ em. prof. zw. Katolickiego Uniwersytetu Lubelskiego Jana Pawła II \\ oraz Uczelni Państwowej im. Szymona Szymonowica w Zamościu \\ ORCID: 0000-0002-8275-5778
}

\begin{abstract}
Streszczenie. Tekst ma charakter laudacyjnej biografii Jubilata Profesora Feliksa Czyżewskiego, widzianej przez pryzmat nazewnictwa własnego, które wyraża się poprzez dane: antroponimiczne (imię, nazwisko), toponimiczne (miejsca zamieszkania, edukacji, pracy, szlaków przemieszczania się w przestrzeni miejskiej i pozamiejskiej), ideonimiczne (tytuły prac naukowych) oraz chrematonimiczne (godności i odznaczenia).
\end{abstract}

Słowa klucze: nazwy własne w biografii osobistej

Zawarty w powyższym tytule człon życiorys jest w Słowniku języka polskiego Mieczysława Szymczaka krótko zdefiniowany: „opis czyjegoś życia i działalności, biografia" ${ }^{2}$ Z własnego doświadczenia wiemy, że przedstawiając swój życiorys, uwzględniamy w nim różnorakie elementy onimiczne, dotyczące swojego imienia, nazwiska, imion rodziców, miejsca urodzenia, imion rodzeństwa, miejsca zamieszkania, stopnia wykształcenia, typu pracy i jej miejsca, stanu cywilnego oraz statusu etnicznego. Dokładniej jeszcze możemy pisać/mówić o przynależności do różnego rodzaju organizacji społecznych i kościelnych, o ewentualnych swoich osiągnięciach i odznaczeniach, o pozazawodowych zainteresowaniach (hobby), objawiających się np. w podróżach, przyswajaniu artefaktów kulturowych z dziedziny literatury i szerzej sztuki, w wędkowaniu lub upodobaniu do polowań czy łapaniu motyli. W związku z powyższym każdy z nas jest w większym lub mniejszym stopniu wpisany w sieć onomastyczną wyrażoną różnorakimi elementami, które można przyporządkować różnym klasom onimów: antroponimom, toponimom, szeroko pojętym chrematonimom - urabanonimom, nazwom instytucji, organizacji, ideonimom (tytułom dzieł kultury). Kwintesencją jednak życiorysu każdego z nas, sprowadzonego do niezbywalnych elementów onomastycz-

1 Stownik języka polskiego, red. M. Szymczak, t. 3, Warszawa 1981, s. 1097. 
nych, które służą społecznej identyfikacji osoby, jest jej imię, nazwisko, są imiona rodziców oraz miejsce urodzenia.

O naszym Jubilacie - o Nim jako osobnym bycie - decyduje imię Feliks, nazwisko Czyżewski, imiona rodziców Irena, Józef, miejsce urodzenia Jusaki-Zarzeka. Niestałe może być i najczęściej jest miejsce zamieszkania. Z punktu widzenia społecznej komunikacji identyfikację osoby gwarantuje sama forma wskazanych elementów onimicznych, zaś w świetle onomastyki jest inaczej. Onomastów interesuje pierwotne znaczenie tych onimów, co nie ma już wymiaru pragmatycznego, lecz czysto teoretyczny. Wyniki poprawnych analiz onomastycznych przeprowadzone przez specjalistów onomastów, śledzone w zamkniętym gronie naukowców, mogą być skierowane do szerszego odbiorcy, stanowiąc skierowaną do niego intelektualną ofertę poznawczą. Stąd w moim tekście, opartym na kanwie życiorysu prof. Feliksa Czyżewskiego, wpisanego we wskazaną wyżej sieć onomastyczną w bogatym zakresie, znajdą się wielowątkowe jej nici, budujące życiorys onomastyczny Jubilata.

Od dnia chrztu świętego nosi nasz Jubilat niezmienne imię Feliks. Jest to miano chrześcijańskie pochodzenia łacińskiego w znaczeniu 'urodzony, żyzny, szczęśliwy, błogi', mające za patrona męczennika rzymskiego $\mathrm{Fe}$ liksa ${ }^{2}$, dla którego odpowiednikiem spolszczonym jest thumaczenie jako Szczęsny // Szczesny - imię notowane w antroponimii staropolskiej od 1422 roku $^{3}$, potem występujące wyjątkowo. Jan Grzenia w Stowniku imion z 2002 roku odnotowuje tylko 131 Polaków noszących to tak wiele obiecujące imię . Pod względem znaczeniowym pokrewne $\mathrm{z}$ nim jest bizantyjskie miano Makar(ej), z gr. makár 'szczęśliwy's, od czego pochodzi m.in. nazwisko autora tego tekstu. Jesteśmy zatem obaj onomastycznie spokrewnieni, nie po mieczu, nie po kądzieli, ale po onomastyce. Rodzicom i ich potomkowi Jubilatowi należy pogratulować wyboru tego szczęsnego - choć w wariancie obcym - imienia. Tu chciałoby się, jako rzecze imię, powiedzieć $\mathrm{Na}$ szczęście, na zdrowie.

Imię Feliks w umiarkowanym stopniu jest notowane w antroponimii staropolskiej od 1202 roku$^{6}$. W Stowniku imion wspótcześnie w Polsce używanych z roku 1995, odnotowującym stan z 1993 roku, imię Feliks nosiło 34549 osób $^{17}$. Jak pokazuje Krystyna Nowik, liczba ta plasowała to miano w rankingu najpopularniejszych 100 imion na odległej 83 pozycji, przy czym nosili je

\footnotetext{
M. Malec, Imiona chrześcijańskie w Polsce, Kraków 1994, s. 215.

Stownik staropolskich nazw osobowych, t. 5, red. W. Taszycki, Wrocław 1977-1980,

J. Grzenia, Stownik imion, Warszawa 2002, s. 302.

M. Malec, op. cit., s. 284.

Stownik staropolskich nazw osobowych, t. 2, red. W. Taszycki, Wrocław 1969, s. 29.

Słownik imion wspótcześnie w Polsce używanych, wyd. K. Rymut, Kraków 1995, s. 131.
} s. $291-292$. 
głównie panowie mniej lub bardziej stateczni ${ }^{8}$. W rankingu z 2018 roku imię to zajmuje jeszcze niższą - 91 pozycję, przy czym panowie Feliksowie stali się jeszcze bardziej stateczni, a Felusiów w całej Polsce w tym samym czasie na świat przyszło jak na lekarstwo - tyko 296. Mój Władysław jest jeszcze niżej - na 110 miejscu z liczbą tylko 160 nowych Władysławów ${ }^{9}$. W takiej sytuacji pociechą dla wszystkich tak niepopularnych Feliksów i Władysławów winna być odczuwana przez ich nosicieli wyjątkowość tych nominacji - o wartości cennych numizmatów.

Drugim niezbywalnym elementem w nazwie Jubilata jest jego nazwisko Czyżewski, odziedziczone po ojcu i przodkach, sięgające w przeszłość bliżej nieokreśloną, może nawet do epoki staropolskiej, kiedy pojawiło się szlacheckie nazwisko na -ski, oznaczające przynależność miejsca do jego właściciela. Był to wówczas sposób nominacji właściwy wysokiej warstwie społecznej. Zatem Czyżewski mógł być właścicielem miejscowości o nazwie dzierżawczej Czyżew, notowanej na Mazowszu - po jednym razie w byłym woj. konińskim i płockim oraz gniazdo aż 10 Czyżewów w łomżyńskim ${ }^{10}$. Bez szlacheckiego stanu posiadania mógł być jednak dawny Czyżewski także przybyszem z którejś z tych miejscowości, gdyż przynależnościowy suf. -ski taką relację mógł również wyrażać. Zważywszy na miejsce urodzin Jubilata - Jusaki-Zarzeka, wsi położonej na terenie środkowego Podlasia, korzeni przodków Feliksa Czyżewskiego należałoby szukać wśród wymienionych łomżyńskich Czyżewów. Zauważmy, że nazwisko Czyżewski i jego podstawa toponimiczna Czyżew- zachowują suf. -ew- w historycznej postaci po spółgłosce kiedyś miękkiej, co jest cechą obszarów wschodniej i północnej Polski, podczas gdy na pozostałym terenie na miejscu takiego przyrostka pojawiło się pod koniec epoki staropolskiej -'ow- jako przejaw wyrównania do tego wzorca, obsługującego formy z twardym tematem. Odpowiednikiem nazwiska Czyżewski na tym terytorium było i jest nazwisko Czyżowski.

Potem ta sama prestiżowa społecznie formacja słowotwórcza na -ski została wykorzystana do tworzenia nazwisk mieszczańskich i jeszcze później chłopskich z XVIII i początku XIX wieku, kiedy zaistniał obowiązek urzędowej rejestracji dotychczasowych niestabilnych w stosunku do imion drugoskładnikowych mian osobowych, nadający im status dziedziczonych nazwisk familijnych. W tym wypadku chodziłoby o zmianę Czyża na Czyżewskiego, tak jak w podobnych operacjach wymiany Stowika na Stowikowskiego, Gasiora na Gąsiorowskiego, Ćwiktę na Ćwiklińskiego ${ }^{11}$, z wykorzystaniem for-

\footnotetext{
$8 \quad$ K. Nowik, Zmiany frekwencyjne w zasobie imion w Polsce powojennej, [w:] Najnowsze przemiany nazewnicze, Warszawa 1998, s. 68.

9 Ranking imion nadawanych w 2018, [źródło internetowe:] https//akademiaporodu.pl/blog/ ranking-imion-2018-najpopularniejsze-imiona, dostęp: 30.11. 2020.

10 Wykaz urzędowych nazw miejscowości w Polsce, t. 1, Warszawa 1980, s. 290.

11 J. Bystroń, Nazwiska polskie, Lwów 1936, s. 103.
} 
mantu -ski, -ewski, -owski, -iński w funkcji strukturalnej jako wykładnika nazwiska sztucznego, kancelaryjnego, a ze względu na jego nacechowanie emocjonalne - upiększonego. Jeśli już do takiej zmiany Czyża na Czyżewskiego w rodzinie Czyżewskich dawno temu miało dojść, to od dobrej czy złej woli urzędnika zależało, który decydował, czy nosiciel przezwiska $C z y z ̇$ pozostał nadal $C z y \dot{e} e m$ - a żona jego będzie Czyżowa lub gdy się zestarzeje $C z y z ̇ y c h a$ i wszystkie dzieci będą Czyżami - czy też mąż i tata będzie się już ładniej nazywał za pomocą formantu -ewski, co mogło nominata kosztować np. gęś, a może nawet prosię.

Ten sam formant $\mathrm{w}$ postaci sufiksalnego -ski lub dwumorfemowego -ewski/-owski w nazwiskach interpretowanych jako odmiejscowe jawi się w swojej funkcji lokalizującej formantu przynależnościowego, który był także, choć nie powszechnie, wykorzystywany w funkcji dzierżawczej odosobowej. Wtedy Czyżewski oznaczałby syna Czyża, czyli znaczyłby tyle, co Czeżewicz czy wcześniej po staropolsku Czyżewic z suf. -ic-jednoznacznym wykładnikiem posesywnego nazwiska polskiego.

Badacz w sytuacji widocznej tu homonimii, spowodowanej szeroką pojemnością słowotwórczego modelu na -ski przy niejednoznaczności podstaw, jest bezradny w ustaleniu bezsprzecznej genezy takiego nazwiska. A o dawnej staropolskiej lub nowszej średniopolskiej albo nowopolskiej metryce może zdecydować rodzinna wiedza na temat statusu społecznego przodków szanownego Jubilata.

Bardziej precyzyjni możemy być w ustaleniu stratygrafii nazwiska $C z y$ żewski. Należy ono do dawnej warstwy nominacji osobowych. Jest kilka razy odnotowane w Stowniku staropolskich nazw osobowych ${ }^{12}$, występuje w całej dobie średniopolskiej na wschodzie Polski, Pomorzu i w Wielkopolsce, zgodnie z zasięgiem suf. -ew- po spółgłosce miękkiej ${ }^{13}$. Jak podaje Jarosław Maciej Zawadzki, w roku 2000 miano to było notowane 9514 razy, co stanowi, że w rankingu 1000 najpopularniejszych nazwisk polskich w tym czasie zajmowało 426 pozycję po Bielawskim, a przed Misiakiem. Było wtedy Czyżewskich 21 razy mniej niż Nowaków, 14 razy mniej niż Kowalskich i 11 razy mniej niż Wiśniewskich, którzy zajmują trzy czołowe miejsca w rankingu polskich nazwisk ${ }^{14}$.

Czy to 426 miejsce Czyżewskiego na liście naszych nazwisk jest dobre? Niby odległe, ale całkiem przyzwoite, jeśli uwzględnić, że według ustaleń Kazimierza Rymuta liczba nazwiskowych form w dzisiejszej Polsce przekracza 400 tysięcy.

\footnotetext{
12 Stownik staropolskich nazw osobowych, t. 1, red. W. Taszycki, Warszawa 1965, s. 444-445.

13 Antroponimia Polski od XVI do końca XVIII wieku, t. 1: $A-G$, red. A. Cieślikowa, Kraków 2007, s. 341.

14 J.M. Zawadzki, 1000 najpopularniejszych nazwisk w Polsce, Warszawa 2002, s. 280, 292, 297.
} 
Choć Czyżewskiemu tak daleko do przodujących Nowaków, Kowalskich i Wiśniewskich, to ja bym się tym, tak nazwany, nie zadręczał. Sam ze swoim nazwiskiem nie mieszczę się nawet w owym tysiącu. Ale za to ze względu na formant -ski obaj znajdujemy się w klasie najliczniejszych polskich nazwisk na -ski, która obejmuje 1/3 współczesnego polskiego nazwiskowego antroponomastykonu. Zatem wyrównał się deficyt ilościowy związany z imieniem. Imię Feliks, tak jak i Władysław, jest dziś rzadkie, a nazwisko w obu wypadkach na -ski - powszechne i głęboko zakorzenione w przeszłości jest traktowane jako sztandarowe polskie. Mniej typowe są nazwiska z drugiej grupy formalnej z sufiksalnym -k-, -c-, w rodzaju Bielak, Bielik, Bielec, których dopiero razem jest również około $1 / 3$ ogółu nazwisk, pozostałe stanowią formy rozpierzchnięte między liczne struktury morfologiczne. Przykładowo antroponimów pochodnych od popularnej podstawy dębu można doliczyć się około $200^{15}$.

Rozważając różne kwestie związane z nazwiskiem Czyżewski, nie dotknęliśmy jego źródła albo, lepiej powiedzieć w tym wypadku, gniazda, czyli prapoczątku tej nominacji - apelatywu $c z y \dot{z}$, podstawy przezwiska $C z y \dot{z}$, wchodzącego bezpośrednio lub pośrednio poprzez toponim do nazwiska $C z y$ żewski, które niezależnie od jego akademickiej interpretacji powszechnemu odbiorcy kojarzy się przede wszystkim z tym sympatycznym ptakiem.

W Internecie o nim czytamy: „Drobny ptak o długości 11-12 cm, wyraźnie mniejszy i delikatniejszy od wróbla. Samiec z czarną czapeczką i plamką na gardle i szarymi policzkami. Reszta głowy, szyja i pierś żółta, brzuch biały, ciasno kreskowany. Na czarnym skrzydle dwa żółte paski obrzeżenia lotek. Żółte również boki nasady ogona i kuper. Samica bez rysunku na głowie i znacznie mniej żółta" ${ }^{16}$. Dopełnieniem tego barwnego obrazu czyża jest jego analiza lingwistyczna, którą przedstawił Aleksander Brückner: ,czyż, czyżyk, ptak, nazwany od ćwierkania, od pnia kig-, od tego samego, co i w szczygiet (od pnia skig-, bo sk- czy $k$ - w nagłosie stale się wymieniają); nazwy obu ptaszków mają i to spólne, że obie na Śląsk między Niemców powędrowały, bo niem. Zeisig i Stieglitz (miejscowość Steglitz pod Berlinem) są pożyczkami z zachodniej Słowiańszczyzny" ${ }^{17}$.

Jest to więc piękny i miły ptaszek, którego ze względu na jego filigranowy rozmiar i sympatyczne zachowanie nazywamy częściej za pomocą formy hipokorystyczno-deminutywnej czyżykiem. Użyty do nominacji osobowej mieści się w częstych odzwierzęcych nazwach wykorzystujących zasadę metafory. Aleksandra Cieślikowa mówi tu o prawie teriomorfizmu, które obok

15 W. Makarski, Dąb jako baza antroponimiczna, „Roczniki Humanistyczne” 2010, t. 58, z. 6 , s. 142.

16 Internet: Czyż (Carduelis spinus), [źródło internetowe:] ptaki.info/czyż, dostęp: 30.11.2020.

17 A. Brückner, Stownik etymologiczny języka polskiego, Kraków 1927, s. 83. 
antropocentryzmu i konkretności jest wyznacznikiem potocznej odmiany ję$\mathrm{zyka}^{18}$. Jak na przezwisko - z natury o nacechowaniu negatywnym - nadawane komuś przez złośliwych sąsiadów, mamy tu do czynienia ze społeczną inną nominacyjną postawą - aprobatywną. To nie jest groźny Wilk, chytry Lis, potężny Niedźwiedź, czarny, złowieszczy Kruk, krzykliwa Sroka, ale miły $C z y \dot{z}$. Nawet można trochę żałować, że tak sympatyczny $C z y \dot{z}-$ jeszcze sympatyczniejszy byłby $C z y z \dot{y} k$ - ukrył się w dłuższej formie nazwiska $C z y$ żewski. Inaczej mielibyśmy miana Feliks Czyż albo Feliks Czyżyk, co jednak pod względem formalnym nie dorównuje fonetycznej frazie Feliks Czyżewski, o czym jeszcze niżej.

O ile omówiony wyżej człon nazwiskowy Czyżewski w złożonej nazwie osobowej Jubilata jest automatycznie niejako odziedziczony, o tyle imię $\mathrm{Fe}$ liks jest elementem nadanym przez rodziców. Nie wiadomo w społecznym odbiorze, jaka była motywacja wyboru dla syna Czyżewskich takiego właśnie imienia: czy honorująca jakiegoś członka rodziny ówczesna moda na to imię, czy dzień narodzin, wyznaczający świętego patrona? Należy jeszcze wziąć pod uwagę motywację akustyczną, by dopasować imię pod względem brzmieniowym do nazwiska, a przynajmniej uniknąć pod tym względem dysonansu między tymi członami. W badanej złożonej formie antroponimicznej należy dostrzec, że z ich połączenia wyszła kompozycja udana pod względem walorów fonetycznych. Przyjrzyjmy się jej po akademicku uważnie jako egzemplifikacji fonetyki onomastycznej.

Feliks Czyżewski jest harmonijnym dwusegmentowym wyrażeniem, tworzącym pięciosylabową frazę akustyczną $\mathrm{Fe}$-liks-/Czy-żew-ski, z dwiema dwugłoskowymi otwartymi sylabami nagłosowymi w imieniu $F e$ - i nazwisku $C z y$-, dopełnionymi również dwiema sylabami zamkniętymi: czterogłoskowym liks- oraz trójgłoskowym -żew-. Całość jest zwieńczona również trójgłoskową sylabą otwartą -ski. Cechą spajającą całą frazę jest podobna struktura użytych tu samogłosek: trzy są z rejestru wysokiego - $i 2$ razy oraz 1 raz $y$, a $z$ rejestru średniego -2 razy $e$. Rytm całości został uzyskany poprzez akcent dynamiczny inicjalny: na $\mathrm{Fe}$ - i paroksytoniczny na -żew-, z ostatnią sylabą zamykającą frazę intonacyjną -ski. Wszystko to sprawia, że analizowane miano osobowe wymawia się gładko bez zgrzytów spółgłoskowych, bo nawet w czterogłoskowej sylabie -liks- ze względu na otwarty charakter szczelinowe $s$ zbliża się do otwartych samogłosek, które decydują o tonicznym, a nie szmerowym charakterze każdej wypowiedzianej formy językowej, tu wyrażonej pięcioma wokalicznymi elementami. Wokalizm ten wspierają też odpowiednie spółgłoski: szczelinowe $f, w$, dwukrotne $s, \dot{z}$, półotwarte $l$

18 A. Cieślikowa, Miejsce przezwiska $w$ systemie antroponimicznym. Historia a wspótczesność, [w:] Przezwiska i przydomki w językach słowiańskich, cz. 1, red. S. Warchoł, „Rozprawy Slawistyczne" 1998, t. 14, s. 73. 
- wszystkie w jakimś stopniu otwarte niczym klasyczne samogłoski. Na tle tej płynnej całości dla ożywienia jak wykrzyknik brzmi zwartowybuchowa spółgłoska $k$ w końcowych sylabach obu członów: imienia i nazwiska badanej frazy akustycznej.

Brzmiała ona inaczej po staropolsku. Dziś wszystkie samogłoski frazy Feliks Czyżewski poza $y$ sytuują się w trójkącie samogłoskowym na jego przedniej linii, choć $y$ jest trochę cofnięte, ale i ono kiedyś po historycznie miękkiej $c z$ było realizowane jak $i$. Było więc w nazwiskowej cząstce nagłosowej $C z i z \dot{z}$-, ale w zakończeniu -ski samogłoska $i$ dla odmiany była realizowana $\mathrm{w}$ postaci $y$, więc wymawiano ten przyrostek jako -sky. Pamiętajmy ponadto, że miękkie było kiedyś również $\dot{z}$, całość więc brzmiała jeszcze w XV wieku Cziżiewsky. Nawet dla Polaka brzmi to dziś karkołomnie, żeby nie powiedzieć precyzyjniej ,językołomnie". Jest inaczej i bardzo dobrze, i bardzo ładnie. Wiadomo, że zmiana tej starej formy na dzisiejszą to przejaw uproszczenia artykulacyjnego (miękkie spółgłoski wymawia się trudniej niż twarde, bo pomija się w artykulacji ruch grzbietu języka ku palatum), co mogło dotyczyć także w imieniu Feliks grupy li, która w lokalnej realizacji jawi się jako ly, wiec nasz Feliks mógłby być, a może w rodzinnych stronach jest Felyksem w Lublynie, choć neutralne, a nie historycznie miękkie $l$ występuje w formie zdrobniałej Felek zamiast stp. Fieliek. Tenże Feliks od biedy mógł brzmieć jeszcze inaczej. Jako zapożyczenie z języka łacińskiego mógł być na grunt polski zaadaptowany z zachowaniem pewnych staropolskich tendencji fonetycznych. Samogłoska $e$ w grupie $F e$ jako przednia mogła spowodować zmiękczenie owego $f$, byłoby wtedy Fieliks, por. łac. imię Febronis przyjęte na grunt stp. jako Fiebron ${ }^{19}$, a w innym kontekście fonetycznym łac. Stephanus jako Szczepan (tu poprzez medium czeskie), potem dopiero Stefan. A to z Feliksem zawiłości fonetycznych jeszcze nie koniec. Język prasłowiański, a później polski u swoich początków nie miał spółgłoski $f$ i bywało, gdy zapożyczał obcy wyraz z tą głoską, to owo szczelinowe $f$ zastępował najbliższą artykulacyjnie dwuwargową, ale zwartowybuchową $p$ lub $b$, stąd to $p$ w podanym wyżej przykładzie Szczepan, por. także łac. Fabianus jako stp. Pabijan ${ }^{20}$, łac. ferula jako berto, niem. Farbe jako barwa. Wtedy Feliks byłby Peliksem lub Beliksem, a jeśliby uwzględnić zmiękczającą funkcję $e-$ Pieliksem lub Bieliksem. Feliks, mając imię Szczęsny w siebie wpisane, szczęśliwie nie poddał się opresyjnemu systemowi polskiej fonetyki i pozostał Feliksem, wiernym oryginałowi łacińskiemu, przeszedł próbę ognia, tak jak wielokrotnie czynił to egipski ptak Feniks z popiołów.

19 M. Malec, op. cit., s. 215.

20 Ibidem, s. 301. 
Wracamy do biografii Jubilata i jej innych językowych wyznaczników.

W wymiarze ściśle rodzinnym wyznaczonym przez osoby rodziców, rodzeństwa i kolejnych krewnych, stanowiących familijny układ interpersonalny Jubilata, ważne miejsce zajmuje jego związek małżeński z Danuta z Kiryków. Jako małżeństwo tworzą oni wraz z potomstwem: Anna, Przemystawem, Piotrem i Pawtem oraz wnukami Patrycją, Szymonem, Kamilem piękną, kwitnącą, życiodajną antroponimiczną gałąź, która wyrasta z pnia genealogicznego obojga małżonków. Dokonany na początku tzw. nowej drogi życia akt ślubu to dla nich drugi po dowodzie obowiązkowy tekstowy identyfikator osoby dotyczący jej stanu cywilnego. Następny tego rodzaju konieczny dokument, czekający na nas wszystkich, to będzie akt zgonu, znajdujący odbicie na płycie nagrobnej czy tylko skromnej tabliczce w formie sprowadzonej jedynie do dwóch elementów antroponimicznych: imienia i nazwiska, zamkniętych datami urodzin i śmierci. Tym obligatoryjnym elementom mogą towarzyszyć, ale już niekonieczne, inne inskrypcje nagrobne. Elementy antroponimiczne napisów nagrobnych stały się przedmiotem badań Profesora Feliksa Czyżewskiego. Na razie odłóżmy jednak tego rodzaju myśli i życzmy sobie, a Jubilatowi najbardziej plurimos annos.

Nakreślona droga życia Jubilata, jak każdego z nas, wpisuje się w nurt życia społecznego, kiedy nieustannie poszerzają się nasze kontakty z różnymi środowiskami ludzkimi: na etapie dzieciństwa - z kolegami z podwórka czy miejsca zabaw, w trakcie edukacji podstawowej i średniej - z grupami klasowymi, na etapie kształcenia akademickiego - z grupami ćwiczeniowymi czy seminaryjnymi, w pracy zawodowej, organizacjach społecznych czy komisjach - ze współpracownikami, w bytowaniu domowym - z bliższymi i dalszymi sąsiadami. Każdy z nas nosi w swojej pamięci odpowiedni, stale poszerzający się rejestr ludzi sobie znanych i ciągle poznawanych. Nasz Jubilat nosi go w bogatym wymiarze. Zna wielu, a wielu zna jego. Przeszedł przez wszystkie etapy edukacji, od szkoły podstawowej w Łomazach poczynając, poprzez Liceum Ogólnokształcące w Białej Podlaskiej, Uniwersytet Marii Curie-Skłodowskiej w Lublinie. Po studiach pracował jako nauczyciel w Liceum Ogólnokształcącym w Wisznicach (1972-1975), od roku 1975 wszedł na ścieżkę działalności naukowo-dydaktycznej w macierzystym UMCS-ie w Instytucie Filologii Słowiańskiej, pełniąc w przyszłości funkcję jego dyrektora oraz kierownika Zakładu Filologii Ukraińskiej. Swoją rzetelną pracą badawczą i nauczycielską służył także innym placówkom akademickim: wspierał Katedrę Języka Polskiego i slawistykę KUL-u - prowadząc zajęcia slawistyczne, integrował dwa lubelskie uniwersytety, za co niniejszym wyrażam Mu serdeczne podziękowanie. Pracował także na rusycystyce w Wyższej Szkole Zawodowej w Zamościu. Profesor Feliks Czyżewski, realizując rzetelnie swoje stałe zawodowe obowiązki naukowo-dydaktyczne, wykazywał i wykazuje aktywność w organizowaniu akcji popularyzatorskich, w tym prowadzonych od lat 
konferencji naukowych w Woli Uhruskiej. Zorientowany w swoich badaniach na pogranicznych stosunkach językowych polsko-ukraińskich jest wiceprzewodniczącym PAN-owskiej Komisji Polsko-Ukraińskich Związków Kulturowych Oddziału PAN w Lublinie. W uznaniu zasług naukowych i organizacyjnych był wielokrotnie nagradzany medalami, orderami, odznaczeniami, dyplomami w rodzaju: Srebrny i Złoty Krzyż Zastugi, Nagroda Ministra Nauki Szkolnictwa Wyższego, Tytut Honorowego Obywatela Gminy Wola Uhruska, Medal Zastużony dla Towarzystwa Ziemi Wtodawskiej, Medal Pamiatkowy Województwa Lubelskiego za Zastugi na Rzecz Upowszechnienia Kultury Polskiej za Granicą. Takich dowodów uznania zebrało się kilkanaście. Te zaszczytne nominacje, przypisane określonej osobie, zyskujące status swoistej nazwy własnej, ozdabiają kreślony tu portret onomastyczny Jubilata.

Dzisiejsza jubileuszowa uroczystość poświęcona Profesorowi Feliksowi Czyżewskiemu, związana z nadaniem Mu honorowego obywatelstwa Włodawy, jest szczególnym przejawem uhonorowania Uczonego i uznania jego zasług za działalność na rzecz tego regionu, wyrastającą przede wszystkim z podstawowej bazy badawczej Profesora, jaką są podlaskie zjawiska językowe $\mathrm{w}$ odmianie dialektalnej i wspomniana już historyczna antroponimia badana na podstawie inskrypcji nagrobnych.

I tu otwiera się kolejny nurt onomastycznej biografii Jubilata - bodajże najważniejszy: to jego twórczość naukowa, objawiająca się w licznych publikacjach książkowych, artykułach i recenzjach oraz w działalności redakcyjnej - w obu nurtach aktywności naukowej z dominującą tematyką dialektologiczną o wymiarze słowiańskim oraz etnolingwistyczną i onomastyczną, zorientowaną w dużym stopniu na region Uczonemu szczególnie bliski - Podlasie. Z punktu widzenia przyjętej w niniejszej charakterystyce sylwetki Profesora Feliksa Czyżewskiego narracji onomastycznej wszystkie te pozycje w liczbie ponad 200 jednostek stanowią artefakty podporządkowane tytułom, które są kwalifikowane ze względu na swoją każdorazową wyjątkowość także jako nazwy własne, choć w odróżnieniu od klasycznych onimów osobowych, miejscowych czy wodnych, funkcjonujących dziś jako jednostki asemantyczne, są w pełni nacechowane znaczeniowo i z tego powodu nazywają się ideonimami. Stanowią one zbiór otwarty na nowe odpowiednio zatytułowane publikacje. Tytuły te jako tematy ewokują różnorakie treści, które wraz z lekturą innych autorów kształtują wiedzę naukową Uczonego. Ten, korzystając z cudzej lektury, tworząc własne teksty, sam badany obszar badawczy poszerza, wpisując się owocnie w nurt polskiej nauki.

Adam Mickiewicz we wstępie do II księgi Pana Tadeusza napisał:

Kto z nasz tych lat nie pomni, gdy, młode pacholę,

Ze strzelbą na ramieniu świszcząc szedł na pole,

Gdzie żaden wał, płot żaden nogi nie utrudza,

Gdzie przestępując miedzę nie poznasz, że cudza. 
Nostalgiczna wizja kraju lat dziecinnych, przywołana przez poetę $\mathrm{z}$ dalekiego Paryża, ewokuje i nasze wspomnienia tych lat. Czy młody Felek, choć bez strzelby, tak jak Adaś Mickiewicz, nie hasał po polach i lasach okolicznej Zaklęsłości Łomaskiej? Spędzając dzieciństwo i młodość w Zarzece, na pewno biegał nad rzekę, by pławić się w niej w skwarze lata, które dawniej nie kaprysiło, a może także by łowić raki, które powinny jeszcze wtedy tam być. A mógł Felek tylko polegiwać w cienistym chłodzie gruszy $-\mathrm{z}$ tych co jak na Litwie z rzadka na miedzach siedzą - i nic nie robić, tylko obserwować: O! tam biegnie zając, zając, a tu z furkotem podfruwają spłoszone przepiórki, na szachownicy pól faluje zboże, czerwienią się w nich maki, po niebie płyną chmury „,napuszyście", a ich cienie na łące kładą się - zupełnie po leśmianowsku - w odstępach nierównych, w kępie traw cieszy się w słońcu żółto-niebieski maleńki bratek, pachnie łubinem, koniczyną i macierzanką. Czysta liryka. Liryka, liryka, tkliwa dynamika - deklarował poeta. Uczony by powiedział: pejzaż uczuciowy, na który wtedy byliśmy niejako skazani, bo bez komórek i smartfonów wszystko można było zobaczyć, usłyszeć, dotknąć, powąchać tylko na żywo.

Ale gdzie tu jest życiorys onomastyczny Jubilata? Odpowiedzmy: Przecież na tę otwartą szeroką przestrzeń nakłada się gęsta siatka mikrotoponimów - nazw pól, ugorów, łąk, lasu, rzeki. Miał świadomość topografii terenu dorastający Felek, a potem dorosły Feliks, uczestniczący w pracach polowych, przy żniwach, wykopkach, w sianokosach, gdy chodził do lasu na grzyby, jagody czy maliny. Wtedy orientował się w tej przestrzeni na podstawie dokładnie zapisanej w swojej świadomości terenowej mapy toponimicznej. Choć dziś już tam nie mieszka, ów kod nazewniczy zapewne zachowuje w swojej serdecznej pamięci. Z owego przywiązania do wiejskiego krajobrazu wyrosła jego pasja badawcza: rejestracja oraz interpretacja faktów językowych społeczności zamieszkujących i zagospodarowujących taką przestrzeń.

Swoje badania gwaroznawcze i antroponimiczne oparł Uczony na sieci 44 punktów osadniczych środkowego i południowego Podlasia oraz Chełmszczyzny w Atlasie gwar polskich i ukraińskich okolic Włodawy, w studium Fonetyka i fonologia gwar polskich i ukraińskich potudniowo-wschodniego Podlasia oraz w monografii Antroponimia pogranicza polsko-wschodniostowiańskiego $w$ świetle inskrypcji nagrobnych. Kierując się zasadą wyboru miejsca według określonych kryteriów, poddał się żmudnej eksploracji terenowej poszukiwanego materiału lingwistycznego. Każdy badany nazewniczo-osadniczy punkt $\mathrm{w}$ przestrzeni zyskał dodatkowe nacechowanie znaczeniowe: 'w tym miejscu mówi się tak', 'w tym podobnie', a 'w tym jeszcze inaczej'. Tam sieje się hreczkę, tam grykę, a tam tatarkę; tam kwitną chabry, a gdzie indziej bławaty; tam się je galarete, tam trzęsionke, a tam studzień. $\mathrm{Z}$ tym cmentarzem wiąża się takie nazwiska, a z innym - takie. Cechy te $\mathrm{w}$ formie graficznej kwadracików, kółek i innych symboli zostały pracowicie naniesione na poszczególne punkty nazewniczo-osadniczej mapy. Razem, od- 
bijając geograficzną przestrzeń onomastyczną (nazwy punktów osadniczych) oraz dodaną (lingwistyczną, dialektologiczną, wpisaną w onomastyczną), tworzą swoisty tekst. Ma on strukturę utkaną $\mathrm{z}$ wielu narastających w czasie, a także ginących toponimicznych elementów, powiązanych nićmi podobnych szczegółowych typów znaczeniowo-formalnych, tworzonych na zasadzie analogii (z wykorzystaniem prawa ekonomii językowej, skutkującej nierzadko niepożądaną homonimią) i kontrastu (z prawem polaryzacji, wyrastającym z potrzeby społecznej komunikatywności używanego nazewnictwa). Mapa taka z kodem literowym i innym - symbolicznym jest tekstem jak najbardziej zgodnym z etymologicznym znaczeniem tego pojęcia od łac. tekstilis 'utkany, dziany', por. tekstylia, który w odróżnieniu od linearnego tekstu pisanego jest przestrzenny geograficznie ${ }^{21}$.

Wróćmy do Bohatera naszego spotkania.

Dorosły, wykształcony Feliks Czyżewski opuścił rodzinne gniazdo. Warunkowany rodzajem swojej pracy dydaktyczno-naukowej przeniósł się do miasta - Wisznic, a potem na stałe już do Lublina, dzieląc los milionów Polaków, którzy z jego pokolenia i późniejszych generacji przenieśli się ze wsi do miasta. Nie aprobowałby takiej zmiany Jan Kochanowski, który w znanej nam apoteozie wsi pisal:

Wsi spokojna, wsi wesoła,

Który głos twej chwale zdoła?

Kto twe wczasy, kto pożytki

Może wspomnieć zaraz wszytki.

Nie próbujmy - zresztą łatwo było poecie tak się zachwycać, gdy na miejscu dostatek miał wszytek! A nadto zbytek.

Ale cenili sobie również przestrzeń wiejską - bez względu na swój status materialny - jako swojską, świętą w opozycji do cudzej, obcej, jaką jest miasto, przykładowo ubodzy Huculi, którzy się nim wyraźnie gorszyli. Pisał o tym Stanisław Vincenz w Na wysokiej połoninie, jak postrzegana była przez nich Kołomyja, ,gdzie śmierdzi, aż dusi, nie ma wody, nic nie widać, [...] ciasno i strasznie. Stąd też domy nastawiane jeden drugiemu na głowie i tak też biedacy ludzie latami mieszkają, jeden drugiemu nad głową się tłoczą". Nie lepiej jest nawet w stołecznej „Widnie”, gdzie wbrew nazwie, która mówi o widnym mieście, „widno wcale nie jest" ${ }^{\prime 2}$.

\footnotetext{
21 W. Makarski, Nazwy miejscowości dawnej ziemi sanockiej, Lublin 1986, s. 9; idem, Nazwy własne jako wyznacznik wypowiedzi, [w:] Gatunki mowy i ich ewolucja, t. 3, cz. II, red. D. Ostaszewska, Katowice 2007, s. 50.

22 S. Vincenz, Na wysokiej połoninie. Pasmo I. Prawda starowieku. Obrazy, dumy i gawędy z Wierchowiny Huculskiej, Sejny 2002, s. 69, 394.
} 
Nam, przybyszom ze wsi, którzy weszliśmy nieuchronnie w cywilizację miasta, przyszło wpisać się przede wszystkim właśnie w jej przestrzeń onomastyczną, kiedy trzeba było rozpoznać jej mapę topograficzną, wyznaczoną przez różnorodną sieć urbanonimów: nazw dzielnic, osiedli, ulic, placów, parków, stadionów, basenów, kin, teatrów, różnego rodzaju instytucji, fabryk, sklepów, targowisk, banków, zakładów usługowych, przedszkoli, szkół, szpitali, dworców, stacji benzynowych, restauracji, kawiarni, nocnych klubów rozrywkowych, a na koniec cmentarzy. Stanowią one dla mieszkańców nacechowany onimicznie, określony stały albo okazjonalny cel przemieszczania się do nich na podstawie zakodowanej w pamięci urbanistycznej topografii tych miejsc albo odtwarzanej na podstawie mapy lub ustnej informacji napotkanego na drodze przechodnia. Każdy z mapą w głowie lub w ręce ma odpowiednio do lokalizacji swego mieszkania wyznaczone owe kierunki poruszania się po mieście $\mathrm{i}$ - szerzej - po przestrzeni polskiej oraz zagranicznej, choćby w charakterze turysty czy pielgrzyma: jest użytkownikiem wielu ścieżek onomastycznych, w tym serdecznie bliskich ścieżek arkadyjskch. Dla naszego Jubilata punktem startowym wszystkich jego lubelskich ścieżek i innych szlaków przemieszczania się był do niedawna Czechów, ulica Paryska, a ostatnio jest dom w Świdniczku pod Wólką Lubelską - nowe gniazdo rodzinne wpisane znowu w przestrzeń wiejską, z której nasz Jubilat Profesor Feliks (czytaj Szczęsny), Czyż-ewski (czytaj $C z y z ̇$ ) wyfrunął w świat.

Szczęśliwego długiego i wysokiego lotu najserdeczniej życzymy. Szczęść Boże!

Lublin-Włodawa, 7 czerwca 2019 roku

\section{BIBLIOGRAFIA}

Antroponimia Polski od XVI do końca XVIII wieku. 2007-2016. T. 1-6. Red. Cieślikowa A. Kraków: Wydawnictwo LEXIS.

Brückner Aleksander. 1927. Stownik etymologiczny języka polskiego. Kraków.

Bystroń Jan. 1936. Nazwiska polskie. Lwów.

Cieślikowa Aleksandra. 1998. Miejsce przezwiska w systemie antroponimicznym. Historia a współczesność. W: Przezwiska i przydomki w językach słowiańskich. Cz. I. Red. Warchoł S. Lublin: Wydawnictwo Uniwersytetu Marii Curie-Skłodowskiej: 71-80.

Czyżewski Feliks. 1986. Atlas gwar polskich i ukraińskich okolic Włodawy, Lublin: Wydawnictwo Uniwersytetu Marii Curie-Skłodowskiej.

Czyżewski Feliks. 1994. Fonetyka i fonologia gwar polskich $i$ ukraińskich poludniowo-wschodniego Podlasia. Lublin: Wydawnictwo Uniwersytetu Marii Curie-Skłodowskiej.

Czyżewski Feliks. 2013. Antroponimia pogranicza polsko-wschodniostowiańskiego w świetle inskrypcji nagrobnych. Cz. I: Stownik nazwisk. Lublin: Wydawnictwo Polihymnia.

Grzenia Jan. 2002. Stownik imion. Warszawa: Wydawnictwo Naukowe PWN. 
Makarski Władysław. 1986. Nazwy miejscowości dawnej ziemi sanockiej. Lublin: Wydawnictwo Towarzystwa Naukowego Katolickiego Uniwersytetu Lubelskiego.

Makarski Władysław. 2007. Nazwy własne jako wyznacznik typu wypowiedzi. W: Gatunki mowy $i$ ich ewolucja. T. 3. Cz. II. Red. Ostaszewska D. Katowice: Wydawnictwo GNOME: $38-46$.

Makarski Władysław. 2010. Dąb jako baza antroponimiczna. „Roczniki Humanistyczne” LVIII, z. 6: 119-155.

Malec Maria. 1994. Imiona chrześcijańskie w Polsce, Kraków: Wydawnictwo Instytutu Języka Polskiego PAN.

Stownik języka polskiego. 1981. T. 3. Red. Szymczak M. Warszawa.

Nowik Krystyna. 1998. Zmiany frekwencyjne $w$ zasobie imion $w$ Polsce powojennej. W: Najnowsze przemiany nazewnicze. Warszawa: Wydawnictwo Energeia.

Stownik imion współcześnie w Polsce używanych. 1995. Wyd. Rymut K. Kraków: Wydawnictwo Instytutu Języka Polskiego PAN.

Słownik nazwisk współcześnie w Polsce używanych. 1992-1994. T. 1-10. Wyd. Rymut K. Kraków: Wydawnictwo Instytutu Języka Polskiego PAN.

Stownik staropolskich nazw osobowych. 1965-1987. T. 1-6. Red. Taszycki W. T. 7: Suplement. Pod kierunkiem Malec M. Wrocław. Wydawnictwo Polskiej Akademii Nauk Zakładu Narodowego im. Ossolińskich.

Vincenz Stanisław. 2002. Na wysokiej połoninie. Pasmo 1. Prawda starowieku. Obrazy, dumy i gawędy z Wierchowiny Huculskiej. Sejny: Wydawnictwo POGRANICZE.

Wykaz urzędowych nazw miejscowości w Polsce. 1980-1982. T. 1-3. Warszawa.

Zawadzki Jarosław Maciej. 2002. 1000 najpopularniejszych nazwisk w Polsce. Warszawa: Grupa Wydawnicza Bertelsmann Media. Świat Książki.

Internet

Czyż (Carduelis spinus). W: ptaki.info/czyż [Dostęp 30.XI.2020].

Ranking imion nadawanych $w$ 2018. W: https//akademiaporodu.pl/blog/ranking-imion2018-najpopularniejsze-imiona [Dostęp 30.XI.2020].

\section{ONOMASTIC BIOGRAPHY OF THE JUBILARIAN}

Summary. The text is a laudatory biography of Jubilarian Professor Feliks Czyżewski's. It's seen through the prism of proper nouns, which occurs through the following data: anthroponymic (name, surname), toponymic (place of residence, education, work, routes of movement in space and outside the city), ideonymous (titles of thesis) and chrematonimic (ranks and decorations).

Key words: proper nouns in personal biohraphy

\section{ОНОМАСТИЧНИЙ ЖИТТЕПИС ЮВІЛЯРА}

Анотація. Текст має характер похвальної біографії Ювіляра - Професора Фелікса Чижевського, яка сприймається крізь призму власних назв; це виражається в антропонімічних (ім'я, прізвище), топонімічних (місце проживання, освіти, роботи, шляхів переміщування в міському та позаміському просторі), ідеонімічних (назви наукових праць) і хрематонімічних (звання та відзнаки) даних.

Ключові слова: власні назви в особистій біографії 
